\title{
NÄKEMYKSIÄ KUNTOUTUKSEN KEHITTÄMISESTÄ JA SOTE-UUDISTUKSESTA YLI SEKTORI- JA AMMATTIRAJOJEN
}

Kuntoutuksesta ja sen muutoksesta keskustellaan tällä hetkellä Suomessa laajasti yli sektori- ja ammattirajojen. Pirstaleisina pidetyt kuntoutuspalvelut ovat muutospaineen alla samaan aikaan, kun digitalisaatio ja uudet toimintamallit muovaavat perinteistä kuntoutuksen kenttää. Kyse on niin taloudellisesti kuin inhimillisesti merkittävästä toiminnasta. Vuonna 2000 kuntoutuksen kokonaismenot olivat arviolta 1,2 miljardia euroa (STM 2002). Juuri nyt on suunnitteilla sosiaali- ja terveydenhuollon uudistus, jolla tulee olemaan merkittäviä vaikutuksia myös kuntoutukseen, sen järjestämisen tapoihin ja toimintamalleihin.

Tämän vuoksi Kuntoutussäätiö ja Keskinäinen työeläkevakuutusyhtiö Varma toteuttivat kyselyn kuntoutusalan asiantuntijoille, toimijoille ja kehittäjille ympäri Suomen. Kyselyn tarkoitus oli kerätä hajanaisena pidetyn kuntoutuskentän eri ammattilaisten ja asiantuntijoiden näkemyksiä. Vastaajia pyydettiin kertomaan näkemyksensä kuntoutuksen nykytilasta, siitä mitä sote-uudistuksessa tulisi kuntoutukseen liittyen erityisesti ottaa huomioon sekä mistä löytyvät kuntoutuksen tulevaisuuden innovaatiot.

\section{Kyselyn tausta}

Kuntoutussäätiö ja Keskinäinen työeläkevakuutusyhtiö Varma toteuttivat gallup-muotoisen kyselyn 3173:Ile kuntoutusalan asiantuntijalle ympäri Suomen. Vastauspyyntö ver- kossa täytettävään kyselyyn lähetettiin sähköpostitse joukolle, jossa oli laajasti edustettuina tutkijoita, kehittäjiä, kuntatoimijoita ja palveluiden tuottajia kaikilta sektoreilta. Vastausaika oli 2.-10.3.2016, jona aikana 22 prosenttia kyselyn saaneista vastasi kyselyyn. Sähköpostiosoitteet saatiin Kuntoutussäätiön ja Varman ylläpitämiltä yhteystietolistoilta. Kyselyn tarkoituksena oli kartoittaa kuntoutuksen asiantuntijoiden näkemyksiä kuntoutuksen kehittämisestä ja sote-uudistuksesta.

Verkossa toteutettuun kyselyyn vastasi peräti 694 asiantuntijaa, jotka edustivat laajasti kuntoutuskenttää. Heistä noin kolmannes edusti kuntaa, sairaanhoitopiiriä tai vastaavaa tahoa, neljännes oli kuntoutuksen palvelutuottajia ja suunnilleen kuudennes kolmannelta sektorilta (kuvio 1). Loput edustivat suurimmilta osin kuntoutuspalveluiden tilaajaa, työterveyshuoltoa tai "muu, mikä" -vaihtoehtoa. "Muu, mikä" -vaihtoehdon valitsi reilu kymmenes, ja siitä valtaosa edusti tutkimuslaitoksia, korkeakouluja, virastoja tai ammattiliittoja.

\section{Kelan kuntoutukselle paras arvio}

Vastaajia pyydettiin kyselyssä antamaan kouluarvosana (4-10) kysymyksen alle listatuille kuntoutuksen osa-alueille niiden toimivuudesta. Mikään osa-alueista ei saanut yli 8:n keskiarvoa, mutta mikään niistä ei myöskään niin sanotusti jäänyt luokalle (taulukko 1). Ke- 


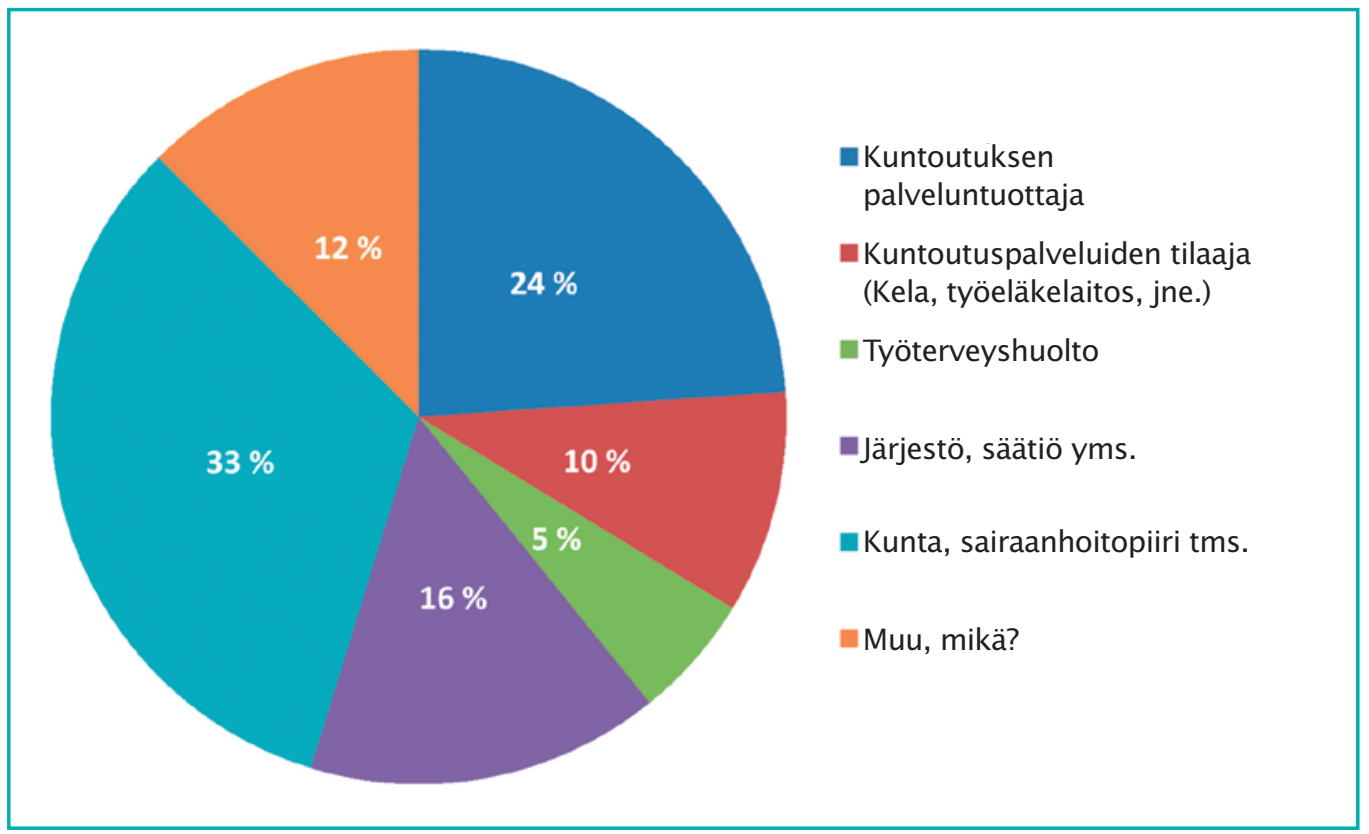

Kuvio 1. Kyselyyn vastanneet $(\mathrm{N}=694)$ taustaorganisaation mukaan, prosenttia.

lan yksilökohtainen kuntoutus arvioitiin parhain arvosanoin, ja sen keskiarvoksi tuli 7,6. Sitä seurasivat työeläkekuntoutus ja Kelan ryhmämuotoinen kuntoutus, joiden molempien arvosanojen keskiarvo oli 7,3. Parannettavaa oli vastaajien mielestä eniten sosiaalihuollon kuntoutuksella, joka sai keskiarvon 6,3.

\section{Kuntoutustarpeen havaitsemista on tehostettava}

Vastaajia pyydettiin nimeämään kolme kuntoutuksen kannalta tärkeintä kysymystä 14

Taulukko 1. Kuntoutuksen osa-alueiden toimivuus vastaajien arvion mukaan, keskiarvo kouluarvosanoista 4-10 ( $\mathrm{N}=675)$.

\begin{tabular}{|l|c|}
\hline Kuntoutuksen osa-alue & Keskiarvo \\
\hline Kelan yksilökohtainen kuntoutus & 7,6 \\
Työeläkekuntoutus & 7,3 \\
Kelan ryhmämuotoinen kuntoutus & 7,3 \\
Kuntoutuksen tutkimus & 6,9 \\
Kuntoutuksen koulutus & 6,8 \\
Terveydenhuollon kuntoutus & 6,8 \\
Sosiaalihuollon kuntoutus & 6,3 \\
\hline
\end{tabular}

vaihtoehdosta. Yli puolet vastanneista piti kuntoutustarpeen havaitsemisen tehostamista kuntoutuksen kannalta tärkeimpänä kysymyksenä, ja se erottui suosiollaan selvästi muista vaihtoehdoista (kuvio 2). Kuntoutustarpeen havaitsemisen tehostamista seurasi kolme suhteellisen tasaisesti valituksi tullutta vaihtoehtoa: työelämässä jaksaminen kuntoutuksen avulla, tasapuolisten kuntoutumahdollisuuksien tarjoaminen eri väestöryhmille sekä kuntoutuksen rahoituksen varmistaminen (42 $\%, 42 \%$ ja $40 \%$ valitsi). Huoli kuntoutuksen rahoituksesta tulevaisuudessa nousi esille myös, kun tiedusteltiin sote-uudistukseen liittyviä uhkia kuntoutuksen kannalta.

Tärkeänä pidettiin myös nuorten syrjäytymisen ehkäisyä, jonka valitsi reilu kolmannes yhdeksi kuntoutuksen tärkeimmistä kysymyksistä. Joka viidennen mielestä kuntoutuksen kytkeminen lääketieteelliseen hoitoon oli kuntoutuksen tärkeimpiä kysymyksiä. Avovaihtoehdon valitsi lähes joka kymmenes, ja siinä tärkeimmäksi kysymykseksi määriteltiin muun muassa kuntoutuksen vieminen arkeen, asiakaslähtöisyys ja kuntoutuksen vaikuttavuuden arviointi. Harvimmin valittuja vaihtoehtoja olivat järjestöjen rooli kuntoutuksen 


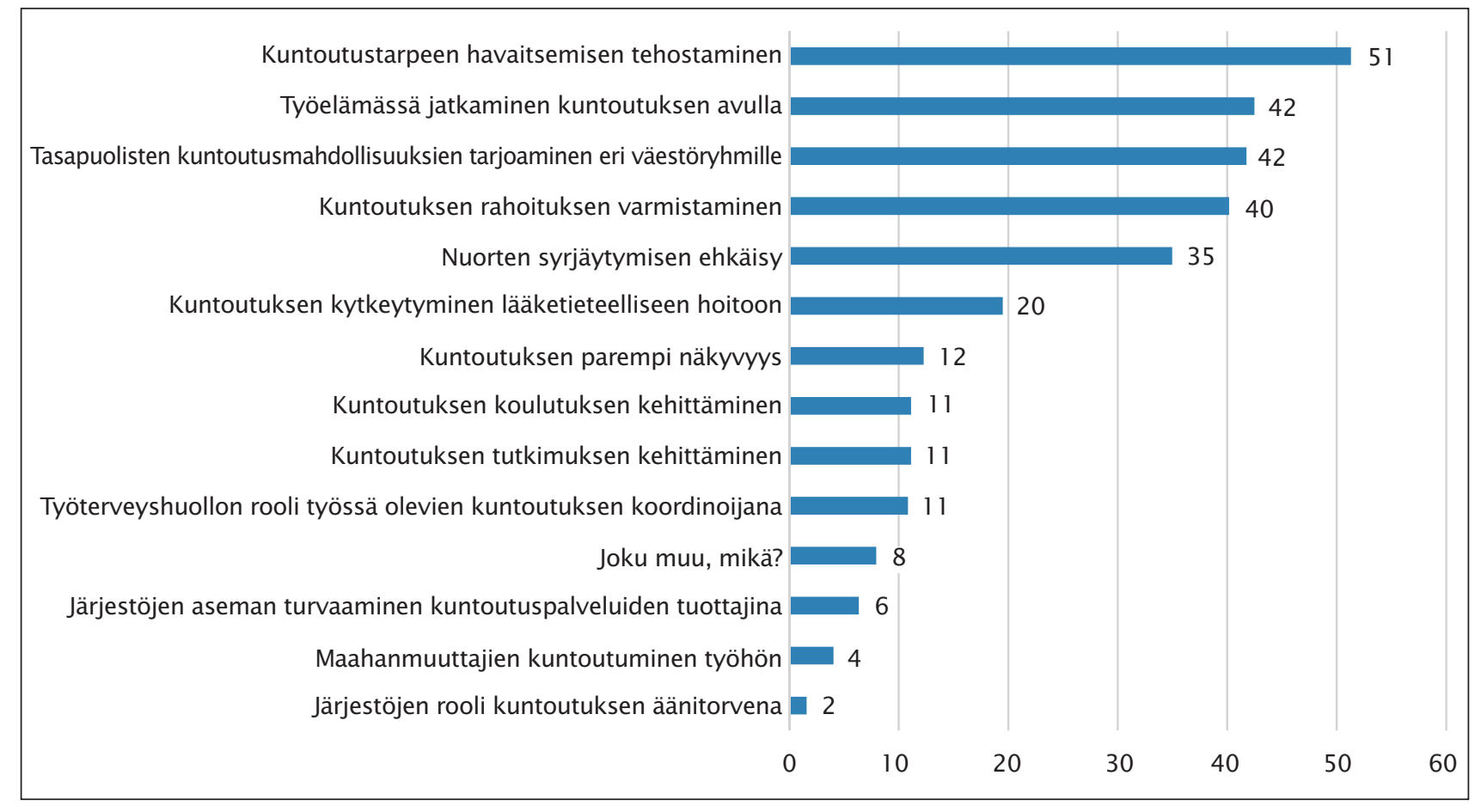

Kuvio 2. Vastaajien näkemys kuntoutuksen kannalta tärkeimmästä ajankohtaisesta kysymyksestä (mahdollisuus valita 3$)$, prosenttia $(\mathrm{N}=692)$.

äänitorvena (2\%), maahanmuuttajien kuntouttaminen työhön (4 \%) ja järjestöjen aseman turvaaminen kuntoutuspalveluiden tuottajina (6 \%).

\section{Päättäjien kuntoutusalan tuntemus arvioitiin heikoksi}

Vastaajat arvioivat päättäjien kuntoutuskentän tuntemuksen heikoksi. Keskiarvo päättäjien kuntoutuskentän tiedoista oli 1,9, kun 1 merkitsi "ei lainkaan" ja 5 "erittäin paljon". Kyse ei vastaajien mielestä ollut ilmeisesti täysin päättäjien kiinnostuksen puutteesta, sillä päättäjien kuntoutusta kohtaan kokema kiinnostus arvioitiin korkeammaksi $(2,3)$ kuin tiedot. Sekä päättäjien kuntoutuksen tuntemuksen että sitä kohtaan koetun kiinnostuksen arvioivat heikoimmaksi työterveyshuollon edustajat (keskiarvot 1,7 ja 2,0). Parhaimmiksi päättäjien tiedot ja kiinnostuksen arvioivat järjestöjen ja säätiöiden edustajat $(2,0$ ja 2,4$)$.

\section{Kuntoutus mukaan sote- keskusteluun, uudistus on mahdollisuus}

Vastaajien arvio sote-uudistuksen merkityksestä kuntoutukselle oli varovaisen myönteinen. Keskiarvo oli 3,1, kun asteikossa 1 oli uhka, 3 sekä uhka että mahdollisuus ja 5 mahdollisuus. Toisin sanoen enemmistö vastaajista taipui arvioimaan sote-uudistuksen joko sekä uhaksi että mahdollisuudeksi tai varovaisesti mahdollisuudeksi. Sen sijaan kuntoutusasiat voisivat olla vastaajien mielestä enemmän esillä sote-uudistukseen liittyvässä keskustelussa. Vastaajien arvioiden keskiarvo kuntoutusasioiden esillä olosta sote-keskustelun yhteydessä oli 2,0, kun 5 pistettä merkitsi "erittäin paljon" ja 1 "ei lainkaan". Toive kuntoutusasioiden esillä olosta ilmeni myös avovastauksissa, joissa esitettiin huoli kuntoutusalan asiantuntijoiden jäämisestä keskustelun ulkopuolelle.

Positiivisimmin sote-uudistukseen suhtautuivat taustaorganisaatiokseen muu-vaihtoeh- 
don (mukana tutkimuslaitoksien, korkeakoulujen, virastojen ja ammattiliittojen edustajia) valinneet (keskiarvo 3,3), kun taas negatiivisimmin kuntoutuksen mahdollisuuksiin soteuudistuksessa suhtautuivat työterveyshuollon edustajat (keskiarvo 3,0). Kuntoutusasioiden esilläolon arvioivat parhaimmaksi kunnan tai sairaanhoitopiirin edustajat (keskiarvo 2,1), kun taas heikoimman arvion antoivat työterveyshuollon edustajat (keskiarvo 1,7).

\section{Uhkana kuntoutuksen huomioimatta jääminen sote-uudistuksessa}

"Ketkä jatkossa pääsevät

kuntoutukseen? Tehdäänkö

tarkempaa valintaa? Miten kuntoutus

toteutetaan? Kuka tai ketkä kantavat

kokonaisvastuuta? Millaisista tarpeista

kuntoutus lähtee liikkeelle?"

- Kunnan, sairaanhoitopiirin tms.

edustaja.

Vastaajilta tiedusteltiin avokysymyksillä soteuudistuksen tuomia, kuntoutukseen liittyviä uhkia ja mahdollisuuksia. Sote-uudistuksen uhkia koskevaan avokysymykseen vastasi 562 vastaajaa. Kuntoutuksen kannalta soteuudistuksen tuomaksi suurimmaksi uhkaksi nimettiin yleisimmin kuntoutusasioiden huomioimatta jääminen sote-uudistuksen yhteydessä, kuntoutukselle suunnattujen resurssien tai lakisääteisen rahoituksen heikentäminen ja pirstaleisuuden jatkuminen. Vastaajat esittivät myös huolensa toisaalta siitä, ettei kuntoutusalan asiantuntijuutta hyödynnetä soteuudistuksen yhteydessä, ja toisaalta kuntoutushyötyjen eli sen kustannustehokkuuden ja inhimillisen merkityksen jäämisestä yhteiskunnallisen keskustelun katveeseen.

"Jos kuntoutuksen tilaajana

ja tuottajana on pelkästään

terveydenhuolto niin se kapeuttaa

kuntoutuksen kohderyhmää ja vaikuttavuutta."

- Kuntoutuksen palvelutuottaja.
Palveluihin liittyviä huolia oli palveluiden eriarvoistuminen ja saatavuuden heikentyminen palveluiden keskittämisen tai karsimisen seurauksena erityisesti pienissä kunnissa. Palveluihin liittyvänä huolena oli myös pienten palvelutuottajien pärjääminen sote-alueilla. Esitettiin huoli myös siitä, että uudistus tapahtuisi järjestelmä-, ei asiakaslähtöisesti ja että tämän takia palvelut irtaantuisivat asiakkaiden arkiympäristöstä.

"Palvelun keskittäminen ei välttämättä

lisää asiakaslähtöisyyttä. Keskittäminen myös voi vähentää hoitavan/ kuntouttavan tahon tietämystä paikallisista haasteista."

- Kuntoutuspalveluiden tilaajan

(Kela, työeläkelaitos jne.) edustaja.

\section{Sote-uudistuksen tuloksena yhtenäisempi kuntoutusjärjestelmä?}

Sote-uudistukseen liittyvien uhkien lisäksi vastaajilta tiedusteltiin, mikä on kuntoutuksen kannalta suurin sote-uudistukseen liittyvä mahdollisuus. Kysymykseen vastasi 550 henkilöä. Sote-uudistukseen liittyväksi mahdollisuudeksi nimettiin useimmissa vastauksissa hajanaisen järjestelmän uudistaminen ja yhtenäistäminen monella tasolla. Ensinnäkin vastauksissa peräänkuulutettiin yhteistyön tiivistymistä palveluntarjoajien välillä, tiedonkulkua eri toimijoiden välillä ja yhteisten tietojärjestelmien kehittämistä. Tämän toivottiin vähentävän asiakkaan turhaa pompottelua, lisäävän kehitystyötä ja uusia innovaatioita sekä vähentävän päällekkäistä työtä.

Samanlaisia vaikutuksia voisi olla palvelujärjestelmän yhtenäistämisellä. Tasa-arvoiset, selkeät ja yhtenäiset kriteerit palveluiden saamiselle sekä monikanavaisen rahoituksen yksinkertaistaminen voisivat vähentää järjestelmän pirstaleisuutta, auttaa kohdentamaan palveluita ja siten lisätä myös niiden saatavuutta. Yhtenäisemmin koordinoidussa järjestelmässä voitaisiin myös hyödyntää erityisosaamista aiempaa tehokkaammin. Suurempien alueiden hallinnointi voi mahdollistaa 
erityisasiantuntijoiden osaamisen hyödyntämisen laajemmilla alueilla.

"Jos yhteistyötä saadaan aidosti kehitettyä kuntoutuksen tarvitsijan kannalta, on sote-uudistus hyvä asia. Samoin [on hyvää] eri toimijoiden kokoaminen yhteen pohtimaan tätä kokonaisuutta päättäjien kanssa. En täysin hahmota sote-uudistuksen vaikutuksia kuntoutujan asemaan.

Tärkeää on saada palvelut juuri kun niitä tarvitaan. Mitä pidempi sairaspoissaolojakso ja työstä poissaolo sitä todennäköisemmin henkilö päätyy ennenaikaiselle työkyvyttömyyseläkkeelle. Toimijoita paljon: Keva, työeläkeyhtiöt, Te-toimisto, työnantajien omat kuntoutukset, Kela, tapaturmavakuutusyhtiöt. Miten näiden toimijoiden toiminta solmiutuu soteuudistukseen?"

- Kunnan, sairaanhoitopiirin tms. edustaja.

Kuntoutuksen asiantuntijoiden toivottiin osallistuvan myös sote-uudistukseen suunnitteluun. Osa vastaajista toivoi kuntoutusta vahvemmin osaksi hoitoketjua ja sen aseman vahvistumista sairaanhoitopalveluiden yhteydessä. Samalla toivottiin kuntoutuksen arvon tunnistamista ja tunnustamista säästöjä ja hyvinvointia edistävänä palvelujärjestelmänä. Yhtenäistämällä kuntoutusta ja tuomalla sen osaksi muita palveluprosesseja voidaan tehostaa toipumista, tukea väestön hyvinvointia ja saavuttaa merkittäviä säästöjä.

"Jos oikeasti leveillä hartioilla [toimittaisiin,] moniammatillisuus kuntoutuksessa pääsisi vaikuttamaan ja mentäisiin kuntoutus eikä sairaanhoito edellä. Mielestäni sairaanhoito tulisi nähdä vain osana kokonaisvaltaista kuntoutusta eikä päinvastoin kuten nykyisin."

- Työterveyshuollon edustaja.
"Mikäli sote-uudistuksen kimpussa työskentelevät päättäjät ja virkamiehet ymmärtävät kuntoutuksen pitkäjänteisyyden ja pitkän aikavälin vaikuttavuuden, kuntoutus on yksi tärkeä mahdollisuus yhteiskunnan kestävyysvajeen korjaamiseksi." - Järjestön, säätiön tms. edustaja.

Joissain vastauksissa pohdittiin kuntoutuksen viemistä osaksi arkea ja asiakkaiden ja vertaisasiantuntijoiden osallistumisen vahvistamista sekä oman kuntoutumisensa että koko järjestelmän suunnitteluun ja kehittämiseen. Asiakaslähtöisyyden toivottiin myös olevan sote-uudistukseen kytkeytyvän kuntoutusjärjestelmän suunnittelun ytimessä.

"Näen, että kuntoutumisessa yleensä ollaan lähdössä hyvään suuntaan, koska entistä enemmän otetaan asiakkaat mukaan suunnittelemaan ja toteuttamaan palveluita. [-] He ovat jo palveluiden ideoinnissa mukana ja ottavat ja saavat eri tavalla vastuuta palvelun toteutuksesta. Heidän omakohtaisia kokemuksia (kokemusasiantuntijat) hyödynnetään sekä asiakkaiden että ammattilaisten hyväksi. He pystyvät myös olemaan oman kuntoutumisensa jälkeen ns. tulkkeina asiakkaiden ja ammattilaisten välissä. Vertaisuuden tulo kuntoutukseen on mahdollisuus, jos sitä osataan hyödyntää ja ottaa huomioon soteuudistuksessa. [Jos] opitaan johtamaan työyhteisöjä joissa mukana toimijoina on sekä ammattilaisia ja vertaisia, niin kuntoutus pääsee aivan uusille urille. Työntekijät eivät ns. "ammu huteja", koska osaavat lukea asiakastaan paremmin ja asiakkaat kohtaavat ja auttavat tosiaan kohtaamaan ammattilaisen enemmän ihmisenä, ei tietäjänä. [Jos näitä asioita] nostetaan esiin myös sotessa, niin silloin se on mahdollisuus."

- Kunnan, sairaanhoitopiirin tms. edustaja. 


\section{Kuntoutuksen innovaatiot syntyvät yhteistyössä asiakkaiden kanssa}

Kysymykseen "Mistä löytyvät kuntoutuksen tulevaisuuden innovaatiot?" annettiin 492 avovastausta. Digitalisaatio, tietotekniikan hyödyntäminen ja hyvinvointiteknologia olivat vastauksissa yleisimmin toistuva teema, johon suhtauduttiin pääosin toiveikkaasti, mutta myös kriittisesti:

"[--] Hyvinvointi- ja terveysteknologiaa ja digitalisaatiota korostetaan liikaa. Toki etäkuntoutustakin tarvitaan mutta kuntoutus on edelleen inhimillistä vuorovaikutusta, jossa yksi tärkeä voimavara on asiakaslähtöinen dialogi."

- Ammattikorkeakoulun edustaja.

Asiakaslähtöisyys ja asiakkaiden kuuleminen toistuivat kommenteissa lähes yhtä usein kuin digitalisaatio tai teknologiset sovellukset. Edellä olevan kaltaiset vastakkainasettelut tietotekniikan hyödyntämisen ja perinteisen vuorovaikutuksen välillä koskivat kuitenkin lähinnä etäkuntoutusta. Useissa puheenvuoroissa digitalisaatio ja asiakasnäkökulman lisääminen nähtiin enemmänkin toisiaan tukevina:

"[Kuntoutuksen innovaatiot löytyvät] digitalisaatiosta, robotiikasta, älylaitteiden hyödyntämisestä järkevällä tavalla niin, että ihmisyyden huomioinnille tulee enemmän tilaa ja aikaa."

- Koulutuksen edustaja.

Toisissa puheenvuoroissa painottuivat ammattilaisten osaaminen ja kokemus, toisissa asiakasnäkökulma. Yksityisen, julkisen ja kolmannen sektorin organisaatioiden yhteistyön, samoin kuin moniammatillisen yhteistyön, puolesta esitettiin paljon kommentteja. Ajatuksen tiivistää erään vastaajan arvio siitä, mistä kuntoutuksen innovaatiot löytyvät:

"Eivät ne löydy, ne luodaan yhteistyössä."

- Korkeakoulun edustaja.

\section{Yhteenveto: Kuntoutuksen tulevaisuuden uhat ja mahdollisuudet?}

Kyselyn vastauksissa toistui usein huoli kuntoutuksen jäämisestä katveeseen sote-uudistuksen yhteydessä. Usein esitetty toive oli, että kuntoutus otettaisiin jatkossa paremmin huomioon sosiaali- ja terveydenhuoltojärjestelmää koskevien uudistusten yhteydessä ja kuntoutuksen asiantuntijoita kuultaisiin soteuudistuksen suunnitteluvaiheessa. Moni piti myös kuntoutuksen vaikuttavuutta aliarvioituna ja aliarvostettuna.

Järjestelmän sisällä suurimmaksi kehittämistarpeeksi yli puolet vastaajista nimesi kuntoutustarpeen havaitsemisen tehostamisen. Erityisen toimivaksi nähtiin Kelan järjestämä kuntoutus, kun taas sosiaalihuollon kuntoutus sai vastaajilta heikoimman arvion.

Päättäjien kuntoutustiedot saivat vastaajilta heikon arvion. Hieman paremmaksi arveltiin kuitenkin heidän kiinnostuksensa kuntoutusasioita kohtaan. Monet vastaajista esittivät, että päättäjien tulisikin sote-uudistuksen yhteydessä kuulla niitä, jotka tuntevat kuntoutusjärjestelmän ja sen vaikuttavuuden hyvin.

Kuntoutusjärjestelmää on pidetty pirstaleisena jo pitkään. Sote-uudistuksen suurimpana uhkana kuntoutukselle monet pitivät pirstaleisuuden jatkumista tai sitä, ettei järjestelmää uudisteta. Vastaajat nimesivät varsinaisten haasteiden lisäksi konkreettisia mahdollisuuksia, joita sote-uudistus kuntoutukselle tuo. Erityisesti vastauksissa nousi esiin järjestelmän yhtenäistäminen palveluntuottajien tiivistyvän yhteistyön, yhtenäisempien palvelunsaannin kriteerien, yhteisen tietojärjestelmän sekä asiakkaiden paremman kuulemisen avulla. Mahdollisuutena pidettiin myös erityisasiantuntemuksen parempaa hyödyntämistä laajemmilla alueilla.

Yhteistyö, digitalisaatio ja asiakaslähtöisyys olivat yleisimpiä vastauksia myös sille, mistä löytyvät kuntoutuksen tulevaisuuden innovaatiot. Moniammatillinen yhteistyö, asiakasymmärrys ja tietotekniikan hyödyntäminen yhdessä kokeilevan kehittämiskulttuurin kanssa luovat vastaajien mielestä hyvät puitteet uusien innovaatioiden syntymiselle. 


\section{Pohdinta}

Kyselyn vastaukset pyörivät tuttujen teemojen ympärillä: kuntoutuksen pirstaleisuus, näkymättömyys ja toisaalta tulevaisuuden mahdollisuudet, joista yhteistyö ja digitalisaatio mainittiin useasti sote-uudistuksen ohella, etenkin tulevaisuuden innovaatioita koskevan kysymyksen kohdalla.

Kuntoutuksen toiminnan pirstaleisuus ja rahoitusjärjestelmän monikanavaisuus on tunnistettu haasteeksi jo pitkään. Vuoden 2002 kuntoutusselonteossa todetaan, että " Kuntoutuksen ympärille on syntynyt monipuolinen, monitahoinen ja monimutkainen rakennelma lainsäädäntöä, palvelujen järjestäjiä, rahoittajia ja tuottajia. Kuntoutuksen kokonaisuuden hahmottaminen on yhä vaikeampaa sekä kuntoutuksesta päättäville että itse kuntoutujille" (STM 2002, 3). Toteamus voisi olla suora lainaus kyselyyn vastanneiden kommenteista. Ei liene ihme, että sote-uudistukselle asetetaan myös paljon odotuksia - useat vastaajat näkivät, että uudistumatta jääminen on sote-uudistuksen suurin uhka. Kuntoutuksen katveeseen jääminen oli toinen toistuva teema kyselyn vastauksissa. Myös tätä aihetta sivuttiin kuntoutusselonteossa, tosin sen toiselta puolelta: Kuntoutuksen vaikuttavuuden lisääminen oli yksi selonteon kehittämislinjauksista. Linjauksen alta löytyi vaikuttavuustiedon hyödyntämisen lisäksi vaikuttavuuden mittaaminen ja seurantamenetelmien kehittäminen. (STM 2002, 20.) Vaikuttavuuden mittaamiseen ja vaikuttavuustietoon panostetaan edelleen liian vähän. Mitä ostetaan kuntoutukseen panostetuilla miljardeilla? Kyse ei voi olla vain toiminnasta ja sen standardeista - vaikuttavuusmittareiden ja näytön avulla huomiota voitaisiin tuoda yhä enemmän pitkäaikaisiin tuloksiin. Esimerkiksi työhön paluuseen johtava työeläkekuntoutus maksaa itsensä takaisin kahdessa vuodessa (Saarnio 2013). Vaikuttavuusnäytön avulla voitaisiin selättää myös sote-uudistuksen uhkakuvat: laadun heikkeneminen ja rahoituksen pieneneminen. Tämä vaatii ennen kaikkea kuntoutusalan asiantuntijoiden tietotaitoa siitä, missä vaikuttavuus näkyy, sekä yhteistyötä oikeiden mittareiden löytämiseksi.
Kolmas kyselyssä kiinnostava pohdinta oli vastaajien näkemykset tulevaisuuden innovaatioista. He uskoivat niiden syntyvän digitalisaation, asiakastyön ja yhteistyön kautta. Pirstaleisuus on osittain sisällä toiminnassa, jossa tieto ei liiku eri toimijoiden tai asiakkaan ja järjestelmän välillä niin kuin pitäisi. Tietotekniikan kehityksen ansiosta näitä haasteita voidaan ratkaista yhä ketterämmin, kun tietoa on yhä helpompi kerätä ja esittää reaaliajassa. Yhteistyön eri muotojen hyödyntäminen, tiedon kerääminen ja esittäminen, yhteiset tietojärjestelmät sekä digitaalinen vertaistieto luovat lukemattomia mahdollisuuksia myös kuntoutukselle. Digitalisaation tuomien mahdollisuuksien hyödyntäminen on kuntoutusalalla vasta aluillaan. Sen vaikutukset kuntoutukselle tulevat luultavasti olemaan soteuudistustakin suuremmat.

Kuntoutussäätiö ja Varma kiittävät lämpimästi kaikkia kyselyyn vastanneita, joita ilman tätä raporttia ei olisi voitu toteuttaa.

\section{Maari Parkkinen, VTM, tutkija, uuden työn muotoilija, Kuntoutussäätiö}

Timo Ilomäki, VTM, tutkimusavustaja, Kuntoutussäätiö

Riikka Shemeikka, VTT, johtaja, tutkimus, Kuntoutussäätiö

\section{Lähteet}

Lillrank P, Reijonsaari K, Heikkilä P, Silander K (2016) Seitsemän syytä sairauteen. Miksi terveydenhuolto ei toimi. Taloustieto OY, Next Print, Helsinki.

Saarnio L (2013) Työeläkekuntoutus vuonna 2012. Eläketurvakeskuksen tilastoraportteja 3. Eläketurvakeskus. Helsinki. Verkossa: http:/www.etk.fi/wpcontent/uploads/Tyoelakekuntoutus_vuonna_2012. pdf. Katsottu 9.5.2016

STM (2002) Kuntoutusselonteko 2002. Valtioneuvoston selonteko eduskunnalle. Sosiaali- ja terveysministeriön julkaisuja 2002:6, Sosiaali- ja terveysministeriö. 